\title{
Toxicity and pathological effects of orally and intraperitoneally administered ivermectin on sea bass Dicentrarchus labrax
}

\author{
F. Athanassopoulou ${ }^{1, *}$, V. $\operatorname{Ragias}^{2}$, M. Roth $^{3}$, N.Liberis ${ }^{4}$, S. Hatzinikolaou ${ }^{4}$ \\ ${ }^{1}$ Deptartment of Fish Diseases and Aquaculture, Athens Veterinary Research Center, National Agricultural Research \\ Foundation, 25 Neapoleos Street, Agia Paraskevi, Athens 15341, Greece \\ ${ }^{2}$ Kavala Fishing Cooperation, Nea Peramos, Kavala, Greece \\ ${ }^{3}$ Aquaculture Solutions, 499 Clarence Street East, Ottawa, Ontario KIP 5E7, Canada \\ ${ }^{4}$ Simi Aquaculture Ltd., 43 Meg. Konstantinou Street, Rhodes 85100, Greece
}

\begin{abstract}
The toxicity and histopathology of ivermectin was studied in 3 and 35 g sea bass Dicentrarchus labrax L. following in-feed, oral intubation and injection administration at dose rates ranging from 0.5 to $3.5 \mathrm{mg} \mathrm{kg}^{-1}$. Estimated $\mathrm{LD}_{50}$ values for $3 \mathrm{~g}$ fish were 0.335 and $0.106 \mathrm{mg} \mathrm{kg}^{-1}$ following oral intubation and injection administration respectively, for fish reared at $11^{\circ} \mathrm{C}_{i}$ and 0.839 and $1.023 \mathrm{mg} \mathrm{kg}^{-1}$ following oral intubation and injection administration, respectively for fish reared at $20^{\circ} \mathrm{C}$. For $35 \mathrm{~g}$ fish reared at $11^{\circ} \mathrm{C}$, the estimated $\mathrm{LD}_{50}$ was 0.523 and $0.361 \mathrm{mg} \mathrm{kg}^{-1}$ following oral intubation and injection administration respectively. No signs of toxicity were observed when the compound was administered via the feed at 0.5 and $0.7 \mathrm{mg} \mathrm{kg}^{-1}$. However, toxicity (> 10\%) was observed at dose rates of $0.2 \mathrm{mg} \mathrm{kg}^{-1}$ and higher when the compound was administered via oral intubation and at $0.5 \mathrm{mg} \mathrm{kg}^{-1}$ when administered via injection. The compound was significantly more toxic to fish reared at $11^{\circ} \mathrm{C}$ than at $20^{\circ} \mathrm{C}$. Further, ivermectin was more toxic to $3 \mathrm{~g}$ than to $35 \mathrm{~g}$ sea bass when administered via injection. Histopathological examination of the major organs revealed pathology was largely restricted to gills and intestinal tissue. In $3 \mathrm{~g}$ sea bass, lesions were also found in the kidneys.
\end{abstract}

KEY WORDS: Ivermectin · Sea bass $\cdot$ Dicentrarchus labrax $\cdot$ Toxicity $\cdot$ Histopathology

\section{INTRODUCTION}

Ivermectin is primarily used to control infections of ectoparasitic copepods or sea lice (Caligus sp. and Lepeophtheirus salmonis) in salmonids and has been used commercially in cage farms in several countries including Ireland (Palmer et al. 1987, Smith et. al. 1993), Scotland (Roth et al. 1993), Canada (Stephen \& Iwama, 1997) and Chile (Gonzalez pers. comm.) and possibly others (Palmer et al. 1997). Ivermectin has also successfully been used for the treatment of other parasitic copepods such as Ergasilus labracis in Atlantic salmon

*E-mail: eathan@vet.uth.gr parr (O'Halloran et al. 1992) and Lernea spp. infections in goldfish (Hyland \& Adams 1987). Recently, copepod and isopod infestations have been reported in cultured marine fish in the Mediterranean region (Athanassopoulou et al. 2001). High mortalities have been recorded through the isopod parasite Anilocra physodes and, to a lesser extent, the copepods Caligus spp. and Lernanthropus kroyeri in juvenile cagereared sea bass and sea bream Sparus aurata L. (Theohari et al. 1997, Athanassopoulou et al. 2001).

In clinical trials, ivermectin has been found to be highly efficacious in the control of copepod and isopod infections in sea bass when administered orally at a dose rate of $0.5 \mathrm{mg} \mathrm{kg}^{-1}$ (Athanassopoulou et al. 2001). While there are several studies on the toxicity of ivermectin to 
salmon (Hoy et al. 1990, O'Halloran et al. 1992, Johnson et al. 1993, Smith et al. 1993, Kilmartin et al. 1997, Palmer et al. 1997) and rainbow trout (Halley et al. 1989) this data is largely restricted to salmonids and does not include fish cultured at warmer temperatures.

The purpose of this present study was to assess the toxicological and histopathological effects of ivermectin in young sea bass reared under both commercial and experimental conditions.

\section{MATERIALS AND METHODS}

In-feed experiment. Acclimatization, diet preparation and feed analysis were as follows:

Fish: From single farm, 400 sea bass Dicentrarchus labrax weighing approximately $3.0 \mathrm{~g}$ were obtained and divided into 4 equal groups of 100 fish each. Each group was put into separate experimental cages measuring $2 \quad 2 \mathrm{~m}$ and placed at the far end of the farm site for dosing at the rates given in Table 1. Fish were acclimatized for $7 \mathrm{~d}$ before the start of the experiment and starved for $3 \mathrm{~d}$ before receiving the medicated diets to ensure maximum uptake of the drug. Mortalities were recorded daily for a period of $113 \mathrm{~d}$. The trial was carried out at $20^{\circ} \mathrm{C}, 30 \% \mathrm{~S}$ and $8.4 \mathrm{pH}$. The doses, schemes, feeding rates and sampling intervals are given in Table 1.

Four days prior to the start of the experiment, 50 fish were sampled from the same source population for bacteriological and parasitological examination. Kidney and spleen samples were inoculated onto tryptone soy agar (TSA) and thiosulphate citrate bile salt agar (TCBS) for bacteriological examination according to the methods described by Roberts \& Shepherd (1997).

Table 1. Experimental conditions and protocols of ivermectin trials in $3 \mathrm{~g}$ sea bass. sid: single dose (administered only once); ${ }^{*}$ : dose administered once a week over a period of $4 \mathrm{wk}$

\begin{tabular}{|c|c|c|c|c|c|}
\hline \multirow{2}{*}{ Parameter } & \multirow[b]{2}{*}{$\begin{array}{l}\text { In feed } \\
\text { (cages) }\end{array}$} & \multicolumn{4}{|c|}{ Method of administration } \\
\hline & & \multicolumn{2}{|c|}{ Intubation } & \multicolumn{2}{|c|}{ Injection } \\
\hline $\begin{array}{l}\text { No. of fish per } \\
\text { cage or tank }\end{array}$ & 100 & 100 & 60 & 100 & 100 \\
\hline Temperature $\left({ }^{\circ} \mathrm{C}\right)$ & 20 & 20 & 11 & 20 & 11 \\
\hline $\begin{array}{l}\text { Dose regime } \\
\text { (mg kg }{ }^{-1} \text { fish) }\end{array}$ & $\begin{array}{c}0.5 \text { wk } 4^{*} \\
0.5^{\text {sid }} \\
0.7^{\text {sid }}\end{array}$ & $\begin{array}{l}3.5^{\text {sid }} \\
2.5^{\text {sid }} \\
1.5^{\text {sid }} \\
1.0^{\text {sid }} \\
0.5^{\text {sid }} \\
0.05^{\text {sid }}\end{array}$ & $\begin{array}{l}3.5^{\text {sid }} \\
2.5^{\text {sid }} \\
1.5^{\text {sid }} \\
1.0^{\text {sid }} \\
0.5^{\text {sid }} \\
0.05^{\text {sid }}\end{array}$ & $\begin{array}{l}0.7^{\text {sid }} \\
0.5^{\text {sid }} \\
0.3^{\text {sid }} \\
0.2^{\text {sid }} \\
0.1^{\text {sid }} \\
0.05^{\text {sid }}\end{array}$ & $\begin{array}{l}0.7^{\text {sid }} \\
0.5^{\text {sid }} \\
0.3^{\text {sid }} \\
0.2^{\text {sid }} \\
0.1^{\text {sid }} \\
0.05^{\text {sid }}\end{array}$ \\
\hline $\begin{array}{l}\text { Sampling } \\
\text { (Days) }\end{array}$ & $\begin{array}{c}2,4,8,15,22 \\
30,45,60,113\end{array}$ & $\begin{array}{c}2,7,14 \\
30,40\end{array}$ & $\begin{array}{c}2,7,14 \\
30,40\end{array}$ & $\begin{array}{c}2,7,14 \\
30,40\end{array}$ & $\begin{array}{c}2,7,14 \\
30,40\end{array}$ \\
\hline Length of experime & $t(d) \quad 113$ & 40 & 40 & 40 & 40 \\
\hline
\end{tabular}

Squash imprints of the gill, skin, gall bladder, liver, spleen, kidney, muscle, brain and gut tissue from freshly killed fish were examined for the presence of parasites according to the methods described by Roberts (1989).

Preparation of diets: Ivermectin used was in the form of a $1.0 \% \mathrm{w} / \mathrm{v}$ veterinary injectable solution (Valaneq ${ }^{\circledR}$ Agvet). The solution was diluted in cod liver oil and top-coated onto a commercial feed with a mechanical mixer. Control fish were fed the same diet mixed with the same quantity of cod liver oil. The diets were freshly prepared before feeding to the fish and were fed ad libitum weekly by hand.

Feed analysis: The levels of ivermectin in treated diets were confirmed by the method of Doherty et al. (1990) at the Toxicology Department of the National Agricultural Research Foundation, Athens, Greece. The doses referred to in the paper are the targeted doses.

Oral intubation experiments. Because the parent compound was not available, 2 experiments were set up: in the first, ivermectin used was in the form of a $1.0 \% \mathrm{w} / \mathrm{v}$ veterinary injectable solution (Valaneq $^{\circledR}$ Agvet). In the second experiment, only the carrier of the commercial compound was used in the same way as in the first experiment. Four separate experiments were carried out using the intubation protocol.

In the first experiment, 200 sea bass weighing approximately $35 \mathrm{~g}$ were acclimated in one large experimental tank for $60 \mathrm{~d} ; 20$ fish were sampled from this population for microbiological and parasitological examination as described for the in-feed experiment. Following the acclimation period, the fish were equally divided between a number of open flow-through system experimental tanks (1.8 $1 \mathrm{~m})$ according to the experimental design shown in Table 2.

In the second experiment, the same protocol was used, but with fish weighing approximately $3.0 \mathrm{~g}$. These fish were equally divided between a number of open flow-through experimental tanks (1.8 $1 \mathrm{~m})$ according to the experimental design in Table 1. Temperature, salinity and $\mathrm{pH}$ were $11^{\circ} \mathrm{C}, 25 \%$ and 8.2 respectively, for experiments 1 and 2 .

For the third experiment, 700 sea bass weighing approximately $3.0 \mathrm{~g}$, obtained from a single population, were transferred to seven $3 \quad 3 \mathrm{~m}$ experimental cages situated at the far end of the farm site; each contained 100 fish (Table 1). Four days prior to the experiment, 50 fish underwent a full microbiological and parasitologi- 
Table 2. Experimental conditions and protocols of ivermectin trials in $35 \mathrm{~g}$ sea bass. sid: single dose

\begin{tabular}{|lcc|}
\hline Parameter & $\begin{array}{c}\text { Intubation } \\
\text { (tanks) }\end{array}$ & $\begin{array}{c}\text { Injection } \\
\text { (tanks) }\end{array}$ \\
\hline No. of fish per tank & 25 & 25 \\
Temperature $\left({ }^{\circ} \mathrm{C}\right)$ & 11 & 11 \\
Dose regime $\left(\mathrm{mg} \mathrm{kg}^{-1}\right.$ fish) & $3.5^{\text {sid }}$ & $0.7^{\text {sid }}$ \\
& $2.5^{\text {sid }}$ & $0.5^{\text {sid }}$ \\
& $1.5^{\text {sid }}$ & $0.3^{\text {sid }}$ \\
& $0.2^{\text {sid }}$ & $0.2^{\text {sid }}$ \\
Sampling (Days) & $0.1^{\text {sid }}$ & - \\
Length of & $0.05^{\text {sid }}$ & - \\
experiment (d) & $2,7,14,30,40$ & $2,7,14,30,40$ \\
& 40 & 40 \\
\hline
\end{tabular}

cal examination using the protocols described for the in-feed experiment. Temperature, salinity and $\mathrm{pH}$ were $20^{\circ} \mathrm{C}, 32 \%$ and 8.9 respectively.

In the fourth experiment, 25 fish were intubated with the carrier at the levels used for the highest dose of the second experiment. All other conditions were similar to that experiment.

All fish were acclimatized for $6 \mathrm{~d}$ prior to the beginning of the experiments. Plastic catheters were fashioned into stomach tubes and used to administer ivermectin by oral gavage. Each dose contained $0.1 \mathrm{ml}$ of sterile saline containing the appropriated amount of ivermectin (as Valaneq ${ }^{\circledR}$ ) which was administered to the fish after slight anaesthesia with dimethyl-ether. All fish were observed for 5 to $10 \mathrm{~min}$ after intubation for regurgitation. Dose rates for the intubation experiments are given in Tables $1 \& 2$.

Injection experiments. Handling, histology and statistical analysis were as follows:

Fish: The same protocols were used for the injection experiments as for the oral intubation experiment. Fish were anaesthetized with dimethyl-ether, weighed and injected intra-peritoneally (i.p.) with $0.1 \mathrm{ml}$ of sterile saline containing the appropriate amount of ivermectin (as Valaneq ${ }^{\circledR}$ ). Dose rates for the injection experiments are given in Tables 1 \& 2; 25 fish were also injected with the carrier at levels used for the highest dose of the i.p. experiment. All other conditions were similar to that experiment.

Histology: In each experimental tank, 10\% of the fish were processed histologically. Tissues of gills, intestine, liver, spleen, stomach, swim bladder and brain were fixed in $10 \%$ buffered formalin, processed and stained with haematoxylin and eosin (H\&E) and Giemsa stains according to the methods described by Drury \& Wallington (1980). Parasitological examination was performed according to the methods described by Roberts (1989), Athanassopoulou (1990) and Yamaguti (1963).
Statistical analysis: $\mathrm{LD}_{50}$ values and $95 \%$ confidence intervals were estimated by probit analysis. Cumulative mortality $40 \mathrm{~d}$ post-administration was used as the end point for the $\mathrm{LD}_{50}$ estimations. Temperature and fish weight effects were compared for pooled data, for 40 d cumulative mortality frequencies, using a chisquare statistic with Yates correction for continuity (Zar 1984).

\section{RESULTS}

\section{In-feed experiments}

The results of the feed analysis are shown in Table 3, and indicate that only a small percentage of the drug was lost by the manual mixing. No abnormal clinical signs, inappetance or mortalities were observed during the period of this experiment in any of the cages, and therefore the $\mathrm{LD}_{50}$ was not estimated.

\section{Oral intubation and injection experiments}

Oral intubation

Cumulative mortality for each intubation treatment is given in Fig. 1. Overall, toxicity was observed $2 \mathrm{~d}$ from administration with the exception of the $35 \mathrm{~g}$ fish treated

Table 3. Results of feed analysis following medication with ivermectin. sid: single dose (administered only once) ${ }^{*}$ : dose administered once a week over a period of $4 \mathrm{wk}$

\begin{tabular}{|c|c|c|c|}
\hline \multirow{2}{*}{\multicolumn{2}{|c|}{ Feeding regime }} & \multicolumn{2}{|c|}{ Ivermectin (mg per $100 \mathrm{~g}$ feed) } \\
\hline & & In diet & Recovered (\%) \\
\hline $0.5 \mathrm{wk}$ & $4{\text { (cages) })^{\text {sid }}}$ & 0.09 & $0.075(83 \%)$ \\
\hline $0.5 \mathrm{wk}$ & 1 (cages) $^{*}$ & 0.09 & $0.08(88.8 \%)$ \\
\hline $0.7 \mathrm{wk}$ & 4 (cages) & 0.12 & $0.095(79 \%)$ \\
\hline
\end{tabular}

Table 4. Toxicity of ivermectin in sea bass after administration viadifferent routes. $\mathrm{LD}_{50}$ values based on $40 \mathrm{~d}$ cumulative mortality

\begin{tabular}{|ccccccc}
\hline Fish wt (g) & $\begin{array}{c}\text { Temp. } \\
\left({ }^{\circ} \mathrm{C}\right)\end{array}$ & $\begin{array}{c}\text { No. fish/ } \\
\text { conc. }\end{array}$ & $\begin{array}{c}\mathrm{LD}_{50} \\
\left(\mathrm{mg} \mathrm{kg}^{-1}\right)\end{array}$ & $95 \%$ CI \\
\hline $\begin{array}{c}\text { Intubation } \\
3\end{array}$ & 20 & 100 & 0.839 & 0.628 & 1.121 \\
3 & 11 & 60 & 0.335 & 0.299 & 0.375 \\
35 & 11 & 25 & 0.523 & 0.340 & 0.805 \\
$\begin{array}{c}\text { Injection } \\
3\end{array}$ & 20 & 100 & 1.023 & 0.739 & 1.415 \\
3 & 11 & 100 & 0.106 & 0.083 & 0.136 \\
35 & 11 & 25 & 0.361 & 0.284 & 0.458 \\
\hline
\end{tabular}



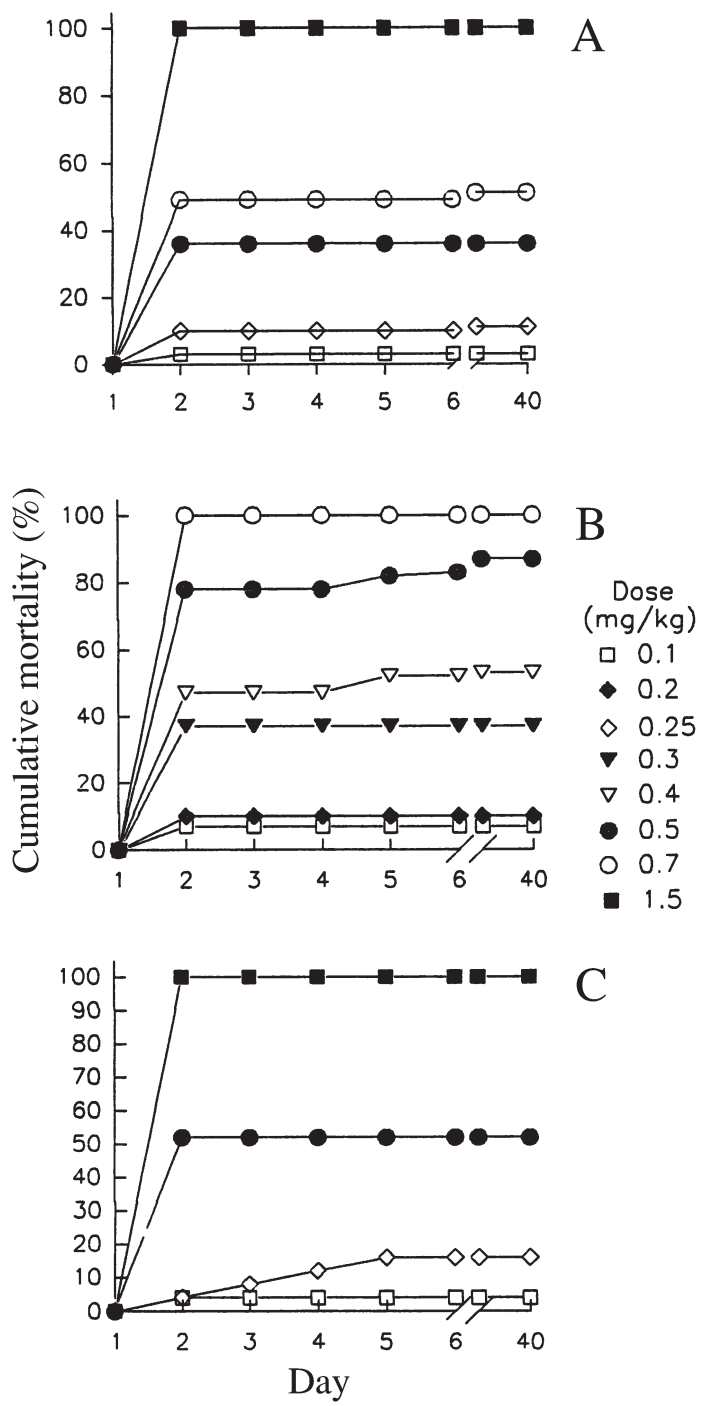

Fig. 1. Dicentrarchus labrax. Cumulative mortality of sea bass following administration of ivermectin by oral intubation (A) $3 \mathrm{~g}$ fish, $20^{\circ} \mathrm{C}$; (B) $3 \mathrm{~g}$ fish, $11^{\circ} \mathrm{C}$; (C) $35 \mathrm{~g}$ fish, $11^{\circ} \mathrm{C}$

with $0.25 \mathrm{mg} \mathrm{kg}^{-1}$ and the $3.0 \mathrm{~g}$ fish $\left(11^{\circ} \mathrm{C}\right)$ treated with 0.4 and $0.5 \mathrm{mg} \mathrm{kg}^{-1}$, in which some delayed signs of toxicity were noted. Toxicity to $3.0 \mathrm{~g}$ fish reared at $11^{\circ} \mathrm{C}$ was statistically greater than to $3.0 \mathrm{~g}$ fish reared at $20^{\circ} \mathrm{C}$ $\left({ }^{2}=34.7 ; \mathrm{p}<0.0001\right)$ (pooled data for $0.1,0.5,0.7,2.5$ and $3.5 \mathrm{mg} \mathrm{kg}^{-1}$ ). However, the difference in toxicity between $3.0 \mathrm{~g}$ fish and $35 \mathrm{~g}$ fish reared at $11^{\circ} \mathrm{C}$ was not statistically significant $\left({ }^{2}=2.53 ; \mathrm{p}<0.1118\right.$ ) (pooled data for $0.1,0.5,2.5$ and $3.5 \mathrm{mg} \mathrm{kg}^{-1}$ ).

\section{IP injection}

Cumulative mortality for each injection treatment is given in Fig. 2. Similar to the intubation toxicity results, toxicity was general apparent within 2 to $3 \mathrm{~d}$ from the start of treatment. A notable exception was the $3.0 \mathrm{~g}$ fish reared at $20^{\circ} \mathrm{C}$, which displayed a more delayed response. Toxicity to $3.0 \mathrm{~g}$ fish reared at $11^{\circ} \mathrm{C}$ was statistically greater than to $3.0 \mathrm{~g}$ fish reared at $20^{\circ} \mathrm{C}$ $\left({ }^{2}=364.5 ; \mathrm{p}<0.0001\right.$ ) (pooled data for 0.05, 0.1, 0.2, $0.3,0.5$ and $0.7 \mathrm{mg} \mathrm{kg}^{-1}$ ). In addition, the drug was found to be significantly more toxic to $3.0 \mathrm{~g}$ fish than to $35 \mathrm{~g}$ fish reared at $11^{\circ} \mathrm{C}\left({ }^{2}=63.7 ; \mathrm{p}<0.0001\right)$ (pooled data for $0.2,0.3,0.5$ and $0.7 \mathrm{mg} \mathrm{kg}^{-1}$ ).

\section{Histology}

No histopathological lesions were observed in any of the organs of all samples of the control fish or the organs of the fish injected or intubated with the carrier.
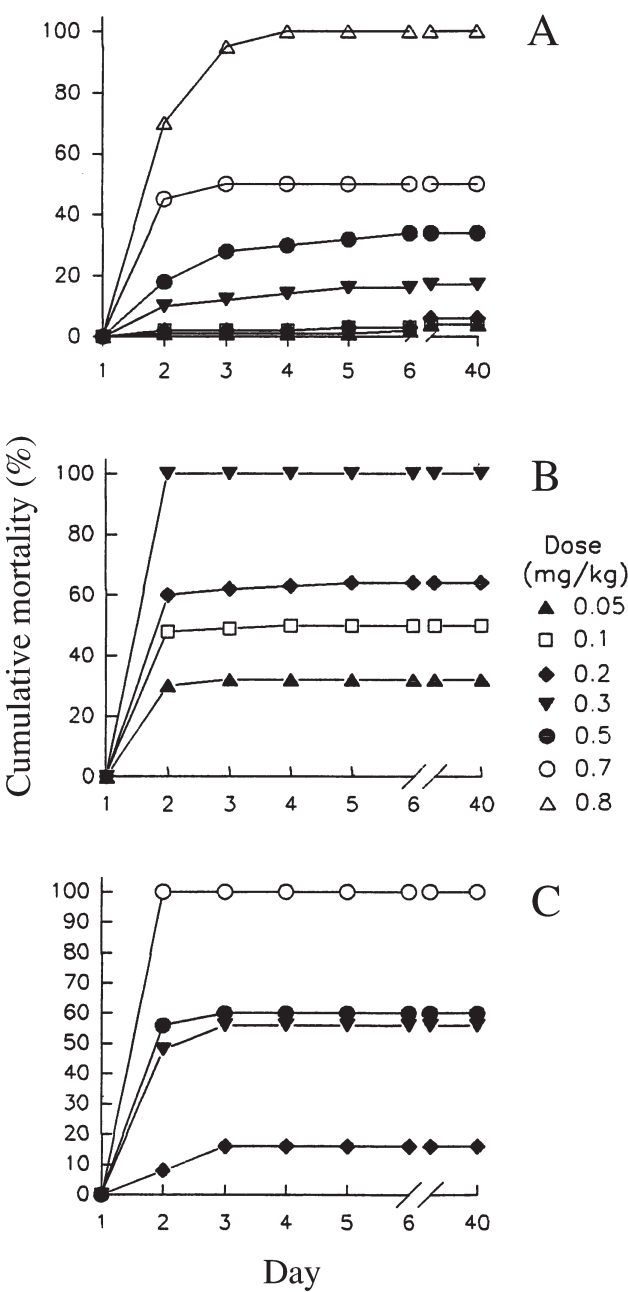

Fig. 2. Dicentrarchus labrax. Cumulative mortality of sea bass following administration of ivermectin by i.p. injection. (A) $3 \mathrm{~g}$ fish, $20^{\circ} \mathrm{C}$; (B) $3 \mathrm{~g}$ fish, $11^{\circ} \mathrm{C} ;$ (C) $35 \mathrm{~g}$ fish, $11^{\circ} \mathrm{C}$ 
Fig. 3. Dicentrarchus labrax. Vacuolization of the epithelium of mucosa in $3 \mathrm{~g}$ fish after administration of ivermectin by oral intubation (1.5 mg kg-1). H\&E ( 400)

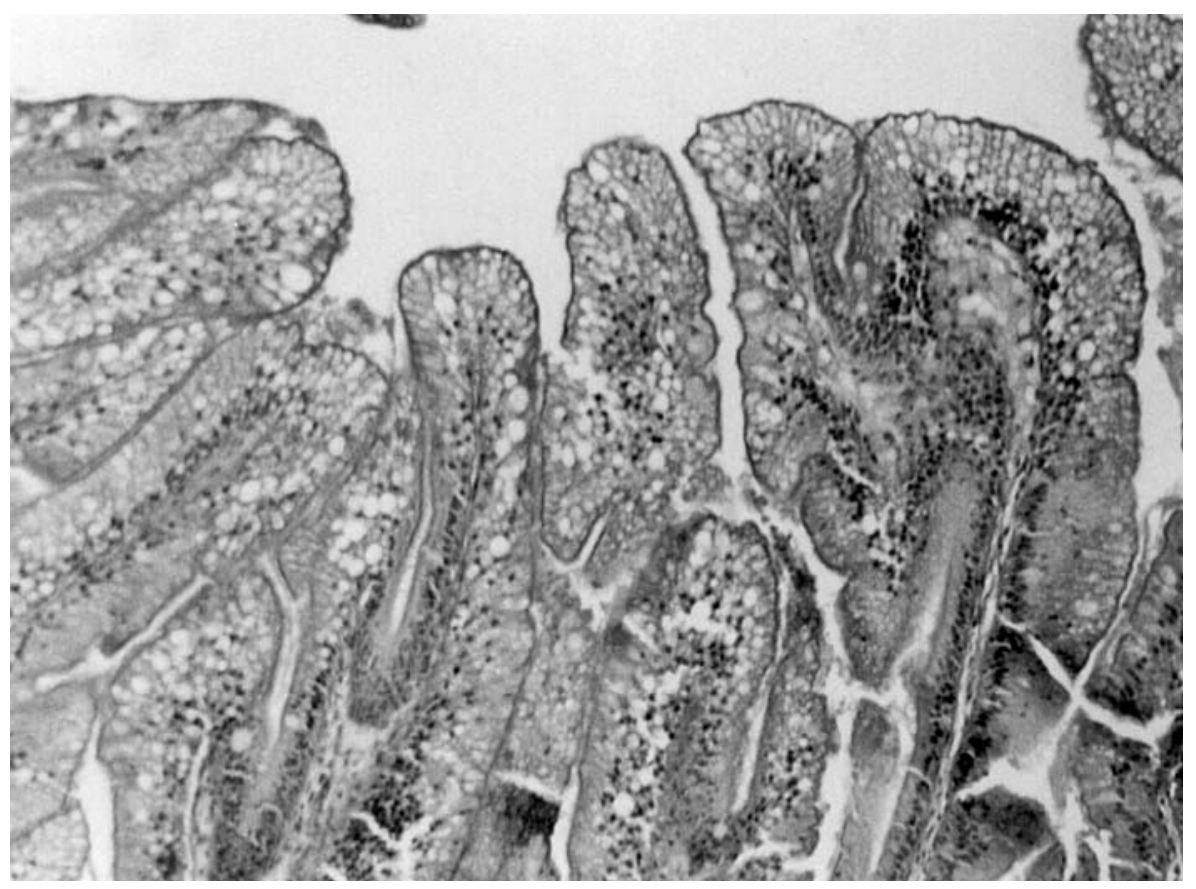

Oral intubation: The $3.0 \mathrm{~g}$ fish given doses of 1.5 , 2.5 and $3.5 \mathrm{mg} \mathrm{kg}^{-1}$ ivermectin by intubation showed marked pathology in the intestine, kidneys and gills. Intestinal tissue displayed necrosis, sloughing and intense vacuolization of the epithelium of the mucosa (Fig. 3) in all fish examined $96 \mathrm{~h}$ post administration and onwards. A focal necrosis in the renal parenchyma was observed in 3 fish from the Day 7 sample of the $3.5 \mathrm{mg} \mathrm{kg}^{-1}$ treatment (Fig. 4), and slight protein deposition in 2 fish from the Day 14 sample. No similar lesions were observed in other samples. The pathology of the gills was similar in all cases and consisted of oedema, necrosis of epithelial cells and sloughing of the secondary lamellae (Fig. 5). In larger fish $(35 \mathrm{~g})$ the lesions in the intestine were similar but not as extensive. No pathology was observed in the kidneys or in any of the other organs of the larger fish.
Fig. 4. Dicentrarchus labrax. Necrotic lesion in the renal parenchyma of $3 \mathrm{~g}$ fish after administration of ivermectin by oral intubation $\left(1.5 \mathrm{mg} \mathrm{kg}^{-1}\right)$. H\&E ( 400)

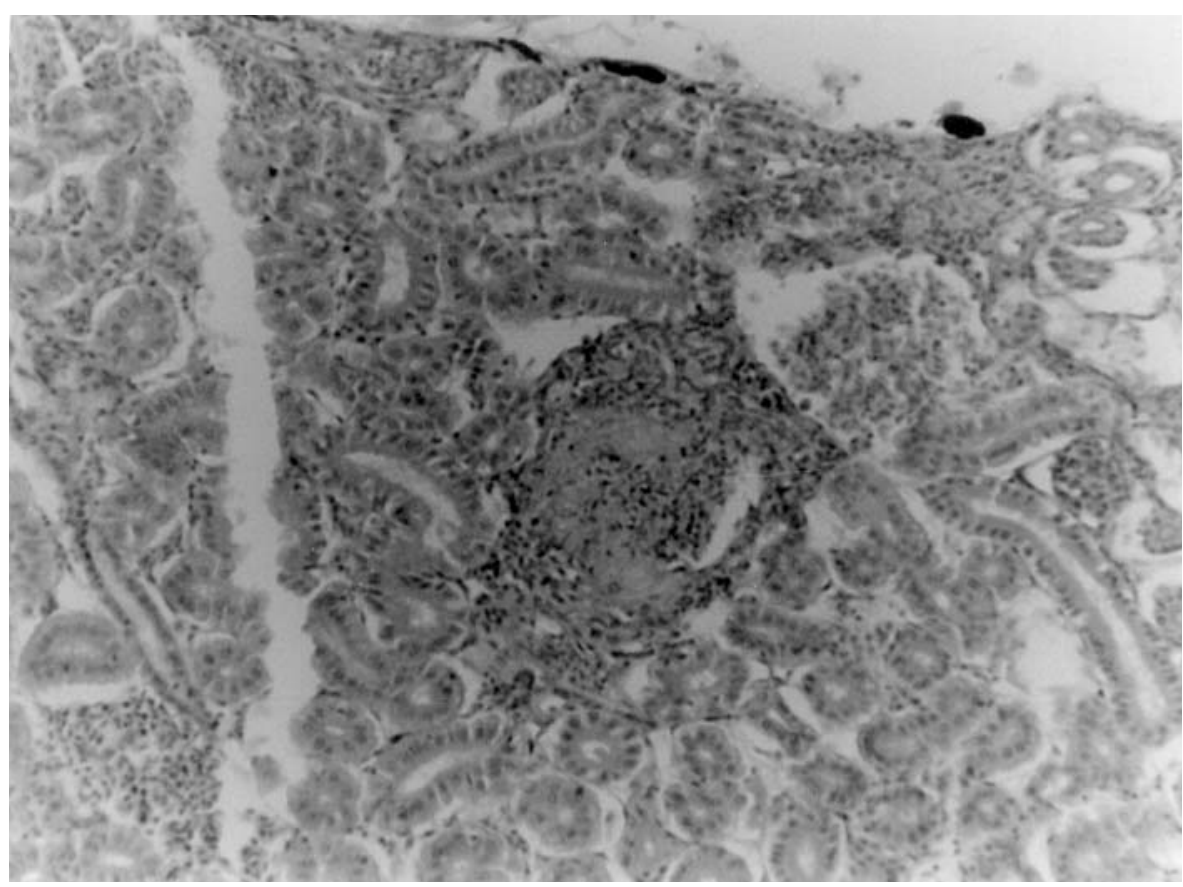




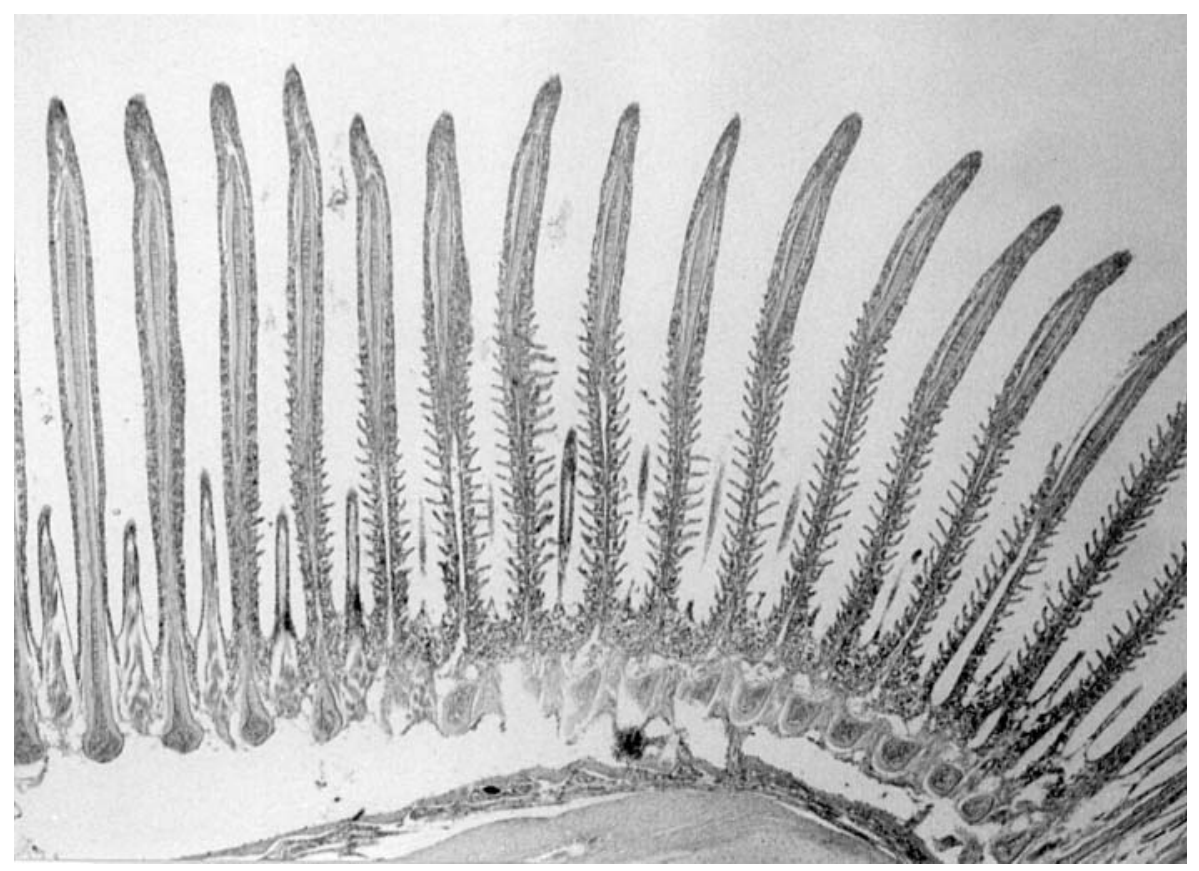

Fig. 5. Dicentrarchus labrax. Sloughing of primary and secondary lamellae of gills in $3 \mathrm{~g}$ fish treated with ivermectin by i.p. injection $\left(0.7 \mathrm{mg} \mathrm{kg}^{-1}\right)$. H\&E ( 200)

IP injection: In $3 \mathrm{~g}$ fish injected with ivermectin at doses of 0.8 and $0.7 \mathrm{mg} \mathrm{kg}^{-1}$ both in tanks and in cages pathology was prominent in the intestine and gills. The intestinal and gill lesions were similar to those described above for fish treated by oral intubation. Similar lesions were seen also in $35 \mathrm{~g}$ fish injected with $0.7 \mathrm{mg} \mathrm{kg}^{-1}$ ivermectin. The pathology of the internal organs appeared on the seventh day of sampling and was consistent in all fish and samples up to the Day 14 sample. The gill lesions were observed up to the $40 \mathrm{~d}$ post-treatment sample.

\section{DISCUSSION}

There is little information available concerning the toxicity of ivermectin in non-salmonid species. When administered by injection at a dose rate of $0.2 \mathrm{mg} \mathrm{kg}^{-1}$, ivermectin was found to be highly toxic to mottled sculpins, Cottus bairdi (Heckman 1985), and eels Anguilla anguilla (Taraschewski et al. 1988), but not to channel catfish Ictalurus punctatus (Lorio 1989) or gold fish (Hyland \& Adams 1987). This is the first report on the toxicity of ivermectin to sea bass.

In salmonids, the fish group in which ivermectin is most commonly used, the drug has been tested mainly in fish infected with sea lice (Lepeophtheirius salmonis and Caligus elongatus). There has been some concern expressed in the literature concerning the safety of oral ivermectin therapy for the target species (Kilmartin et al. 1997). Palmer et al. (1987) showed that feeding Atlantic salmon Salmo salar ivermectin at a dose rate of $0.4 \mathrm{mg} \mathrm{kg}^{-1}$ resulted in a $17 \%$ mortality in treated fish compared with $3.6 \%$ in untreated fish. Smith et al. (1993) conducted several trials taking into consideration these aspects of ivermectin metabolism in their clinical designs, and reported that, with the exception of an accidental overdose (a single dose of $0.75 \mathrm{mg}$ $\mathrm{kg}^{-1}$ resulting in $26 \%$ mortality) that occurred in one trial, no abnormal behavior or death was observed.

The results of the present study, which showed the toxicity of ivermectin to $35 \mathrm{~g}$ sea bass reared at $11^{\circ} \mathrm{C}$, and $3 \mathrm{~g}$ sea bass reared at 11 and $20^{\circ} \mathrm{C}$, are in general agreement with studies of Kilmartin et al. (1997) on Atlantic salmon of $50 \mathrm{~g}$ reared at similar temperatures. These authors reported $\mathrm{LD}_{50}$ values of $0.3 \mathrm{mg} \mathrm{kg}^{-1}$ in brown trout Salmo trutta following i.p. injection and $0.5 \mathrm{mg} \mathrm{kg}^{-1}$ in Atlantic salmon S. salar following oral intubation. While the results reported in the present study were calculated based on $40 \mathrm{~d}$ mortality frequencies, overall little change in mortality was observed after $4 \mathrm{~d}$ in most of the trial. In the case of the $35 \mathrm{~g}$ fish reared at $11^{\circ} \mathrm{C}$, the mortality results were unchanged from Day 4 (96 h) to Day 40. Similar to the observations in the present study, Palmer et al. (1997) reported increased toxicity in Atlantic salmon following treatment with ivermectin at temperatures below $10^{\circ} \mathrm{C}$. It is possible that slower metabolic detoxification due to colder water temperature may allow the drug to sequester in the brain and other central nervous tissue, 
resulting in increased toxicity (Hoy et al. 1990). However, toxicity was markedly reduced in the present study when the compound was administered via the feed at dose rates of 0.5 to $0.7 \mathrm{mg} \mathrm{kg}^{-1}$; this may reflect lower toxicity due to the relatively higher water temperature $\left(20^{\circ} \mathrm{C}\right)$ at which the in-feed trials were carried out. It is likely that toxicity in the feed trials was lower than in the intubation and injection trials due to reduced bioavailbility following incorporation into the feed (Halley et al. 1989).

Histopathology was indicated at the higher dose levels in tissues other than central nervous tissue (gills, kidneys and intestines); this may indicate that other acute toxicological processes were taking place. Palmer et al. (1997) noted similar tissue pathology in moribund Atlantic salmon, namely odematous gills, hepatic necrosis and protein deposition in the kidney tissue. However, these authors also noted that secondary respiratory and osmotic problems might have been implicated. Since neither mortalities nor pathological changes were observed in fish intubated or injected with only the carrier in the present study, it is reasonable to assume that the toxicity and pathological changes observed in the sea bass were due to the compound (ivermectin) and not to the carrier. This is the first report of the pathological effects of ivermectin on sea bass and, in general, the first report on ivermectin pathology related to fish size.

An alternative hypothesis is that sea bass have a higher tolerance to ivermectin than salmonids. Johnson et al. (1993) studied the pathological effects of various doses of the drug administered orally every second day to different species of salmonids and found that the species differed in their ability to tolerate ivermectin, with coho salmon Oncorhynchus kisutch being the most tolerant, followed by chinook $O$. tshawytscha and Atlantic salmon. It should be noted however that some of these fish were of different weight, and the experiments were not run at the same temperatures.

While noting that salmon are susceptible to toxic effects from ivermectin, Smith et al. (1993) and Kilmartin et al. (1997) speculated that overuse of the drug is effectively under its own negative control, as farmers who use too much ivermectin will kill their fish. They concluded that ivermectin remains a good alternative for the infeed treatment of fish parasites. Given that sea bass are a warm-water species normally cultured in areas where the water temperature is above $14^{\circ} \mathrm{C}$ for most of the year, and that ivermectin appears to be less toxic at higher temperatures, we suggest that ivermectin may provide a safe and efficacious chemotherapeutic alternative for parasite control in sea bass. However, fish health practitioners considering the use of ivermectin should note that the drug has not been approved or registered for use in fish in any country to date.

\section{LITERATURE CITED}

Athanassopoulou F (1990) A study of the myxosporean infections of $R$. rutilus L. with special reference to Myxidium rhodei Leger, 1905 in the renal tissue. PhD thesis, University of Stirling

Athanassopoulou F, Ragias V, Tavla J, Christofilogiannis $\mathrm{P}_{1}$ Liberis N (2001) Preliminary trials on the efficacy and toxicity of ivermectin against Lernathropus kroyeri Van Beneden, 1851 in cultured sea bass Dicentrarchus labrax L. Aquac Res 32:77-79

Doherty SJ, Fox A, Fink DW (1990) Determination of ivermectin in medicated swine feeds at the $2 \mathrm{ppm}$ concentration level. J Assoc Off Anal Chem 73:931-934

Drury RA, Wallington EA (eds) (1980) Carleton's histological Techniques, 5th edn. Oxford University Press, Oxford

Halley BA, Jacob TA, Lu AYH (1989) The environmental impact of ivermectin: environmental effects and fate. Chemosphere 18:1543-1563

Heckman RA (1985) The efficacy of ivermectin against nematodes of fish. In: Proceedings of the 60th Annual Meeting of the American Society of Parasitology, Abstract 24

Hoy T, Horsberg TE, Nafstef I (1990) The disposition of ivermectin in Atlantic salmon (Salmo salar). Pharmacol Toxicol 67:307-312

Hyland KPC, Adams SJR (1987) Ivermectin for use in fish. Vet Rec 120:539

Johnson SC, Kent ML, Whitaker DJ, Margolis L (1993) Toxicity and pathological effects of orally administered ivermectin in Atlantic chinook, coho salmon and steelhead trout. Dis Aquat Org 17:107-112

Kilmartin J, Cazabon D, Smith P (1997) Investigations of the toxicity of ivermectin for salmonids. Bull Eur Assoc Fish Pathol 17:58-62

Lorio W (1989) Experimental control of metacercariae of the yellow grub Clinostomum marginatum in Channel Catfish. J Aquat Anim Health 1:269-271

O'Halloran J, Carpenter J, Ogden, CD, Hogans WE, Jansen M (1992) Ergasilus labracis on Atlantic salmon. Can Vet J 33:75

Palmer R, Rodger H, Drinan E, Dwyer C, Smith PR (1987) Preliminary trials on the efficacy of ivermectin against the parasitic copepods of Atlantic salmon. Bull Eur Assoc Fish Pathol 7:47-54

Palmer R, Coyne R, Davey S, Smith PR (1997) Case notes on adverse reactions associated with ivermectin therapy of Atlantic salmon. Bull Eur Assoc Fish Pathol 17:62-68

Roberts RJ (1989) Fish pathology. Bailliere-Tindall, London

Roberts RJ, Shepherd CJ (1997) Handbook of trout and salmon diseases. Fishing News Books, Oxford

Roth M, Richards RH, Sommerville C (1993) Current practices in the chemotherapeutic control of sea lice infestations in aquaculture. A review. J Fish Dis 16:1-26

Smith PR, Moloney M, McElligott A, Clarke S, Palmer, R, O'Kelly J, O'Brien F (1993) The efficiency of oral ivermectin in the control of sea lice infestation of farmed Atlantic salmon. In: Boxhall GA, DeFaye D (eds) Pathogens of wild and farmed fish: sea lice. Ellis Horwood, Chichester, p 296-307

Stephen C, Iwama G (1997) Fish health discussion paper. Technical Advisory Team Discussion Papers, Vol. 3, Part C. Salmon Aquaculture Review. British Columbia Environmental Assessment Office, Victoria, BC

Taraschewski H, Renner C, Melhorn H (1988) Effects of levamisole hydrochloride, metrifonate, fenbendazole, mebendazole and ivermectin on Anguillicola crassus pathogenic in the air bladder of eels. Parasitol Res 74:281-289

Theohari V, Ragias V, Bai C (1997) Identification of the copepods 
Lernathropus kroyeri Van Beneden, 1851 and Caligus minimus Otto, 1821 ectoparasites in the natural and farmed population of Dicentrarchus labrax L. Geotechn Sci Issues 8: 29-38

Editorial responsibility: Wolfgang Körting, Hannover, Germany
Yamaguti S (1963) Systema helminthum Vol I-II. Interscience Publishers, New York

Zar JH (1984) Biostatistical analysis, 2nd edn. Prentice Hall, Englewood Cliffs, NJ

Submitted: August 31, 1999; Accepted: February 5, 2002

Proofs received from author(s): September 17, 2002 